\title{
Characteristics of Heterotrophic Nitrifying and Aerobic Denitrifying Arthrobacter nicotianae D51 Strain in the Presence of Copper
}

\author{
Xi Cai ${ }^{1}$, Kaili Li ${ }^{2}$, Tengxia He ${ }^{1}$, Yaxin Wang ${ }^{1}$, Xue Zhang ${ }^{1}$, Enyu Xie ${ }^{1}$, Ningning Ding ${ }^{1}$ \\ and Zhenlun $\mathrm{Li}^{1, *(\mathbb{D}}$ \\ 1 Chongqing Key Laboratory of Soil Multiscale Interfacial Process, College of Resources and Environment, \\ Southwest University, Chongqing 400716, China; yxcaix@163.com (X.C.); hetengxia5153@163.com (T.H.); \\ 1wyxxxwy@163.com (Y.W.); 18306089819@163.com (X.Z.); xieenyu@outlook.com (E.X.); \\ dinglling@126.com (N.D.) \\ 2 School of Chemical Engineering, University of Queensland, Brisbane, Queensland 4072, Australia; \\ star03344@sina.com \\ * Correspondence: lizhlun4740@sina.com; Tel.: +86-23-68251249; Fax: +86-23-68250444
}

Received: 21 January 2019; Accepted: 24 February 2019; Published: 28 February 2019

\begin{abstract}
A heterotrophic nitrification and aerobic denitrification bacterium, strain D51, was identified as Arthrobacter nicotianae based on morphological, phospholipid fatty acids (PLFAs), and 16S rRNA gene sequence analyses. Further tests demonstrated that strain D51 had the capability to use nitrite, nitrate, or ammonium as the sole nitrogen source in the presence of $\mathrm{Cu}^{2+}$. The maximum removal efficiencies of nitrite, nitrate and ammonium were $68.97 \%, 78.32 \%$, and $98.70 \%$, respectively. Additionally, the maximum growth rate and denitrification capacity of this strain occurred in the presence of $0.05 \mathrm{mg} \cdot \mathrm{L}^{-1}$ of $\mathrm{Cu}^{2+}$.However, the growth and aerobic denitrification capacity were intensively inhibited by $\mathrm{Cu}^{2+}$ at $\geq 0.1 \mathrm{mg} \cdot \mathrm{L}^{-1}$. Moreover, gas chromatography indicated that a portion of the nitrogen was transformed into $\mathrm{N}_{2} \mathrm{O}$ when the nitrite, nitrate, and ammonium were separately used as the sole nitrogen source. This is the first study of the nitrification and denitrification ability of Arthrobacter nicotianae under aerobic conditions, and the first experiment to investigate the impact of $\mathrm{Cu}^{2+}$ concentration on the growth and denitrification ability of this bacteria. The results presented herein extend the known varieties of heterotrophic nitrifying-aerobic denitrifying bacteria and provide useful information regarding the specific bacteria for nitrogen bioremediation of industrial wastewater containing $\mathrm{Cu}^{2+}$.
\end{abstract}

Keywords: Arthrobacter nicotianae; copper; heterotrophic nitrification; aerobic denitrification; nitrogen removal

\section{Introduction}

The increasing emissions of nitrogen contaminants originating from a variety of industries, livestock farms, municipal wastewater, and other anthropogenic sources with urbanization and industrialization have led to serious water eutrophication [1]. Moreover, eutrophication of water poses potential health hazards to both animals and humans. Accordingly, nitrogen bioremediation has been a challenge and a matter of great concern in recent years. Previous studies have shown that aerobic nitrification-denitrification was one of the most environmentally friendly and cost-effective methods of removing nitrogen from wastewater since the discovery of the aerobic denitrifying bacterium Thiosphaera pantotropha [2,3]. When compared with aerobic nitrifier and anaerobic denitrifier, the heterotrophic nitrification-aerobic denitrification bacteria not only have higher growth rates, but are also more efficient at nitrogen removal under aerobic conditions [4]. Therefore, investigations 
of heterotrophic nitrifying and aerobic denitrifying bacteria are important for the development of methods for removal of nitrogen from wastewater.

To date, a number of heterotrophic nitrification-aerobic denitrification bacteria have been isolated and identified, including Vibrio diabolicus [5], Bacillus subtilis [6], Pseudomonas stutzeri [7], and Diaphorobacter sp. [8]. However, no studies have suggested that Arthrobacter nicotianae possess the ability to conduct heterotrophic nitrification-aerobic denitrification. Previous studies indicated that Arthrobacter sp. can reduce alkanes, aromatic hydrocarbons, and N-heterocycles [9]. Additionally, Fu et al. [10] reported that the genus Arthrobacter was capable of heterotrophic nitrification, but not aerobic denitrification. Therefore, this is the first study to show that Arthrobacter nicotianae can perform heterotrophic nitrification and aerobic denitrification in wastewater.

In recent years, water was not only affected by nitrogen pollution, but also by various degrees of heavy metals contamination at the same time [11]. Copper is a heavy metal which is commonly found in wastewater from many industries, including steel mills, currieries, and electroplate factories [12]. Most studies have indicated that these copper-containing industrial wastewaters could have a remarkable influence on the nitrogen removal ability of microorganisms $[13,14]$. Thus, industrial wastewaters containing copper and copper compounds are released to municipal wastewater treatment systems (WWTSs), which decreases biological nitrogen removal performance and makes treatment more complicated [15].

Chen et al. [12] demonstrated that the capacity of anaerobic ammonia oxidation (anammox) bacteria was inhibited when the $\mathrm{Cu}^{2+}$ concentration surpassed $1 \mathrm{mg} \cdot \mathrm{L}^{-1}$. Kimura and Kazuichi reported that the activity of anammox bacteria was decreased by more than $10 \%$ in the presence of $5 \mathrm{mg} \mathrm{Cu}^{2+} \mathrm{L}^{-1}$ [16]. Felgate et al. [17] confirmed that Pseudomonas denitrificans, an anaerobic denitrifying bacterium, had high-efficiency nitrogen removal when the $\mathrm{Cu}^{2+}$ concentration was $0.8 \mathrm{mg} \cdot \mathrm{L}^{-1}$. Ochoa-Herrera et al. [18] found that the $50 \%$ inhibition concentration $\left(\mathrm{IC}_{50}\right)$ of $\mathrm{Cu}^{2+}$ towards aerobic nitrifying bacteria was $26.5 \mathrm{mg} \cdot \mathrm{L}^{-1}$. These reports illustrated that the effects of copper ions on nitrogen removal activity of different bacteria differ.

In this study, a novel nitrification and denitrification bacterium was isolated from the flooded paddy fields and identified as Arthrobacter nicotianae D51 by morphology, phospholipid fatty acid (PLFA) content, and 16S rRNA gene sequence analyses. Additionally, the effects of $\mathrm{Cu}^{2+}$ on the nitrogen removal abilities of strain D51 were investigated when high concentrations of nitrite, nitrate, or ammonium were the sole nitrogen source. Moreover, the intermediate products and $\mathrm{N}_{2} \mathrm{O}$ production were analyzed during the biological nitrogen removal process. The experimental results showed that $A$. nicotianae D51 has heterotrophic nitrification and aerobic denitrification ability in the presence of $\mathrm{Cu}^{2+}$, indicating the potential for its application in the treatment of $\mathrm{Cu}^{2+}$-containing industrial wastewater.

\section{Materials and Methods}

\subsection{Strain and Culture Medium Preparation}

Strain D51, used in this study, was isolated from long-term flooded paddy fields in GuiZhou Province, China. The medium was prepared based on a previously reported method, with minor modifications [19].

Bromothymol blue (BTB) medium contained (per liter) $1 \mathrm{~g} \mathrm{KH}_{2} \mathrm{PO}_{4}, 1 \mathrm{~g} \mathrm{MgSO}_{4} \cdot 7 \mathrm{H}_{2} \mathrm{O}, 0.2 \mathrm{~g}$ $\mathrm{CaCl}_{2} \cdot 7 \mathrm{H}_{2} \mathrm{O}, 0.5 \mathrm{~g} \mathrm{FeCl}_{2} \cdot 6 \mathrm{H}_{2} \mathrm{O}, 1 \mathrm{~g} \mathrm{NaNO}_{3}, 8.5 \mathrm{~g} \mathrm{C}_{4} \mathrm{H}_{4} \mathrm{Na}_{2} \mathrm{O}_{4}, 1 \mathrm{~mL}$ bromothymol blue reagent $(1.0 \%$ in ethanol), and $20 \mathrm{~g}$ agar, $\mathrm{pH}$ 7.2. BTB medium was used for observing the colonial morphology.

Nitrification medium (NM) comprised (per liter) $3.5 \mathrm{~g} \mathrm{~K}_{2} \mathrm{HPO}_{4} \cdot 3 \mathrm{H}_{2} \mathrm{O}, 1.5 \mathrm{~g} \mathrm{KH}_{2} \mathrm{PO}_{4}, 0.1 \mathrm{~g}$ $\mathrm{MgSO}_{4} \cdot 7 \mathrm{H}_{2} \mathrm{O}, 0.236 \mathrm{~g}\left(\mathrm{NH}_{4}\right)_{2} \mathrm{SO}_{4}$, and $2.56 \mathrm{~g} \mathrm{CH}_{3} \mathrm{COONa}$, $\mathrm{pH}$ 7.2. $\mathrm{NM}$ was used when determining the heterotrophic nitrification capacity of strain D51. 
Denitrification medium (DM) comprised (per liter) $3.5 \mathrm{~g} \mathrm{~K}_{2} \mathrm{HPO}_{4} \cdot 3 \mathrm{H}_{2} \mathrm{O}, 1.5 \mathrm{~g} \mathrm{KH}_{2} \mathrm{PO}_{4}, 0.1 \mathrm{~g}$ $\mathrm{MgSO}_{4} \cdot 7 \mathrm{H}_{2} \mathrm{O}, 0.362 \mathrm{~g} \mathrm{KNO}_{3}$ (DM-1) or $0.247 \mathrm{~g} \mathrm{NaNO}_{2}(\mathrm{DM}-2)$ and $2.56 \mathrm{~g} \mathrm{CH}_{3} \mathrm{COONa}$, pH 7.2. DM-1 and DM-2 were used to analyze the capacity of denitrification by strain D51.

Luria-Bertani (LB) medium contained (per liter): $10 \mathrm{~g}$ tryptone, $5 \mathrm{~g}$ yeast extract, and $10 \mathrm{~g}$ sodium chloride, $\mathrm{pH} 7.2$.

Each conical flask ( $250 \mathrm{~mL}$ capacity) containing $100 \mathrm{~mL}$ medium was autoclaved at $0.11 \mathrm{MPa}$ and $121{ }^{\circ} \mathrm{C}$ for $30 \mathrm{~min}$. To explore the effects of different concentrations of $\mathrm{Cu}^{2+}$ on biological nitrification-denitrification of strain D51, different concentrations of membrane-filtered $\mathrm{Cu}^{2+}$ solution were added into $100 \mathrm{~mL}$ NM, DM-1, and DM-2 medium, respectively.

\subsection{Identification of Strain D51}

The colony morphological features of strain D51 were observed after incubation at $15^{\circ} \mathrm{C}$ for 3 days on BTB agar plates. The unicellular morphology of strain D51 was examined under the microscope after Gram staining.

Phospholipid fatty acids (PLFAs) were detected using an Agilent 6850 after saponification, methylation, extraction, and alkali washing of purified strain D51. Fatty acids were then analyzed using the MIDI Sherlock ${ }^{\circledR}$ Microbial identification system (Version 6.1, MIDI, Inc., Newark, DE, USA).

The partial 16S rRNA gene of strain D51 was amplified by polymerase chain reaction (PCR) using the bacterial universal primers 27F (5'-AGAGTTTGATCCTGGCTCAG-3') and 1492R (5'-GGTTACCTTGTTACGACTT-3'). PCR amplification consisted of the following steps [20]: initial denaturation at $94{ }^{\circ} \mathrm{C}$ for $5 \mathrm{~min}$ followed by 30 cycles of denaturation at $94{ }^{\circ} \mathrm{C}$ for $1 \mathrm{~min}$, annealing at $55.5^{\circ} \mathrm{C}$ for $30 \mathrm{~s}$, and extension at $72{ }^{\circ} \mathrm{C}$ for $1 \mathrm{~min}$, and then final extension at $72{ }^{\circ} \mathrm{C}$ for $10 \mathrm{~min}$. The PCR products were analyzed by electrophoresis on an agarose gel and sequenced by Invitrogen. The 16S rRNA sequences obtained from the isolated strain were submitted to the GenBank database for accession number. The sequences of strain D51 were then further used to construct a phylogenetic tree based on the neighbor-joining distance method with bootstrap analyses of 1000 replicates using MEGA 6.06 software.

\subsection{Shake Flask Experiments}

$\mathrm{Cu}^{2+}$ was added to the medium to investigate the growth and nitrogen removal efficiency of strain D51. In the $\mathrm{Cu}^{2+}$ experiments, the content of $\mathrm{Cu}^{2+}$ concentrations in NM, DM-1, and DM-2 were set as $0,0.05,0.1,0.25$, and $0.5 \mathrm{mg} \cdot \mathrm{L}^{-1}$. Individual colonies of D51 were cultured in $100 \mathrm{~mL}$ sterile LB fluid medium at $15{ }^{\circ} \mathrm{C}$ while shaking at $150 \mathrm{rpm}$ for $48 \mathrm{~h}$. Next, $8 \mathrm{~mL}$ of the cells were centrifuged at $6000 \mathrm{rpm}$ for $5 \mathrm{~min}$, then washed once with sterilized water before inoculating into $100 \mathrm{~mL}$ NM, DM-1, and DM-2. Media without $\mathrm{Cu}^{2+}$ were used as control treatments. All experiments were conducted in triplicate and incubated at $15{ }^{\circ} \mathrm{C}$ while shaking at $150 \mathrm{rpm}$. After $48 \mathrm{~h}$ of cultivation, samples were collected to determine the cell optical density $\left(\mathrm{OD}_{600}\right), \mathrm{pH}$, ammonium, nitrate, nitrite, and total nitrogen $(\mathrm{TN})$.

\subsection{Assessment for Gas Detection}

Strain D51 was inoculated into NM, DM-1, and DM-2 (50 mL each) in tightly sealed flasks $(270 \mathrm{~mL})$. A system without strain D51 was used as a control. The entire system was cultivated at $15^{\circ} \mathrm{C}$ while shaking at $150 \mathrm{rpm}$. After $48 \mathrm{~h}$, gas samples were collected using an airtight syringe for detection of $\mathrm{N}_{2} \mathrm{O}$ by gas chromatography (Agilent 7890A).

\subsection{Analytical Methods and Statistical Analysis}

The cell density of strain D51 was assessed based on the $\mathrm{OD}_{600}$ using a spectrophotometer (Beijing Pui General Instrument Co., Ltd., Beijing, China). The $\mathrm{pH}$ was measured using a $\mathrm{pH}$ meter (PHS-4C ${ }^{+}$, Chengdu Century Ark Technology Co. Ltd., Sichuan, China). Nitrite, nitrate, ammonium, and total nitrogen were measured using the supernatant of samples that had been centrifuged at $8000 \mathrm{rpm}$ for 
$5 \mathrm{~min}$. Nitrite nitrogen was investigated using the $N$-(1-naphthyl) ethylenediamine dihydrochloride spectrophotometric method at $540 \mathrm{~nm}$, while nitrate nitrogen was measured using the ultraviolet spectrophotometric method at 220 and $275 \mathrm{~nm}$, and ammonium was detected using the indophenol blue method. Total nitrogen was analyzed using alkaline potassium persulfate digestion. Total and nitrate nitrogen were calculated based on the absorbance at $220 \mathrm{~nm}$ after subtracting two times the absorbance value at $275 \mathrm{~nm}$ [19].

The ammonium, nitrate, nitrite, and total nitrogen removal efficiencies were calculated using the formula $R=\left[1-\left(c_{t} / c_{0}\right)\right] \times 100 \%$ to analyze the aerobic nitrification-denitrification capacity of strain D51, where $R$ was the nitrogen removal rate, and $c_{0}$ and $c_{t}$ were the initial and final concentrations of nitrite, nitrate, ammonium, and TN in culture medium, respectively.

All experiments in this study were performed at least in triplicate, and the results were presented as means $\pm \mathrm{SD}$ (standard deviation of means). Statistical comparisons of variables were conducted by one-way ANOVA with Tukey's HSD test $(P<0.05)$ using SPSS Statistics 19.0. Graphical works were generated using Origin 8.6.

\section{Results}

\subsection{Identification of Strain D51}

Purified strain D51 was streaked onto BTB agar medium and cultured at $15^{\circ} \mathrm{C}$ for 3 days, after which the colony morphology was observed. The single colony morphologies of strain D51 on the BTB plates were viscous, white, opaque, raised, small, and round, with regular edges and smooth, moist surfaces (Figure 1A). Strain D51 was short, rod-shaped, asporulate, without flagella, and Gram-positive (Figure 1B).

Phospholipid fatty acids (PLFAs), which are an important component of the cell membrane, can differ among different microbial communities, but remain constant in the same community [21]. PLFAs have been shown to be a reliable method of identifying bacteria by gas chromatography because their analysis is relatively fast, inexpensive, and simple [22]. In this study, the PLFAs of strain D51 were found to have a 0.504 similarity index (SI) with Arthrobacter aurescens (Table 1). The results were considered credible when the SI values were $>0.5$ based on the principle of PLFAs identification [20].
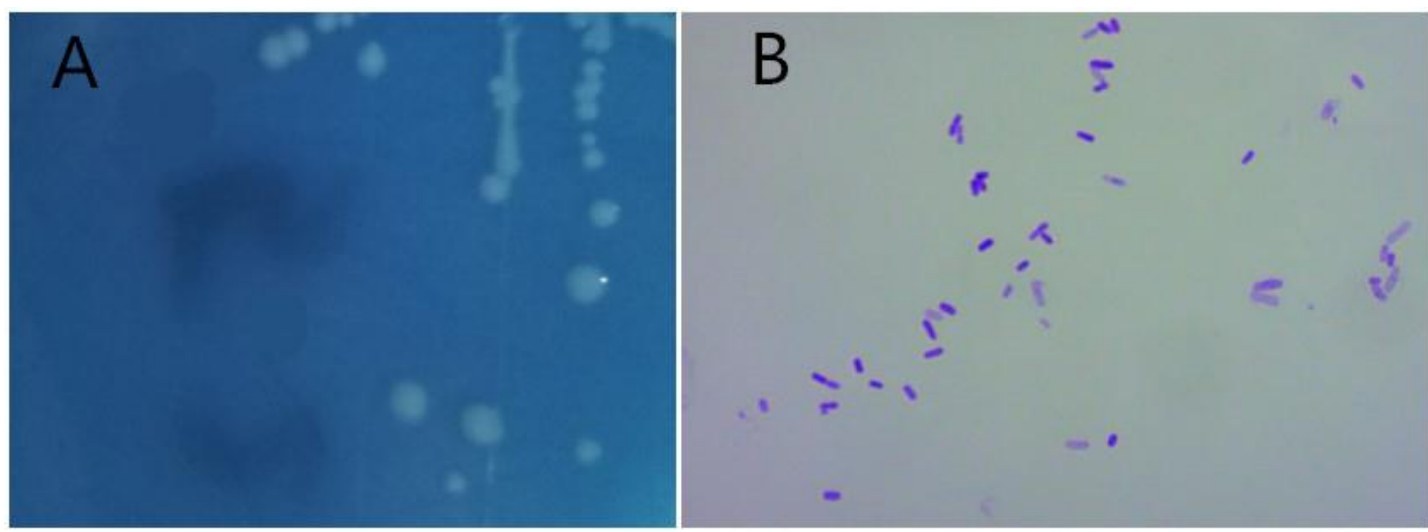

Figure 1. The morphologies characteristics of the strain D51. Single colony morphological characteristic on bromothymol blue (BTB) solid plates (A) and unicellular morphological feature of strain D51 $(10 \times 100)(\mathbf{B})$. 
Table 1. The results of the specific phospholipid fatty acid (PLFA) identification for strain D51.

\begin{tabular}{ccc}
\hline Library & Sim Index & Name \\
\hline TSBA6 6.21 & 0.504 & Arthrobacter aurescens \\
& 0.438 & Bacillus viscosus \\
CLIN6 6.20 & 0.219 & Kocuria varians \\
& 0.185 & Micrococcus luteus GC subgroup A \\
& 0.170 & Bacillus megaterium \\
& 0.168 & Bacillus circulans GC subgroup B \\
\hline
\end{tabular}

The 16S rRNA gene sequences of strain D51, approximately 1379 bp, were obtained via PCR amplification and sequencing. A homology search of the GenBank database was conducted using BLAST and a phylogenetic tree of strain D51 were conducted using MEGA 6.06 software. As shown in Figure 2, strain D51 shared up to 99\% similarity with Arthrobacter nicotianae. The results also confirmed that a legible evolutionary branch of strain D51 was more closely related to Arthrobacter nicotianae than Arthrobacter aurescens. Hence, according to morphological, PLFA, and 16S rRNA gene sequence analyses, strain D51 was further identified as Arthrobacter nicotianae. The accession number of strain D51 in GenBank nucleotide sequence databases is KY927402.

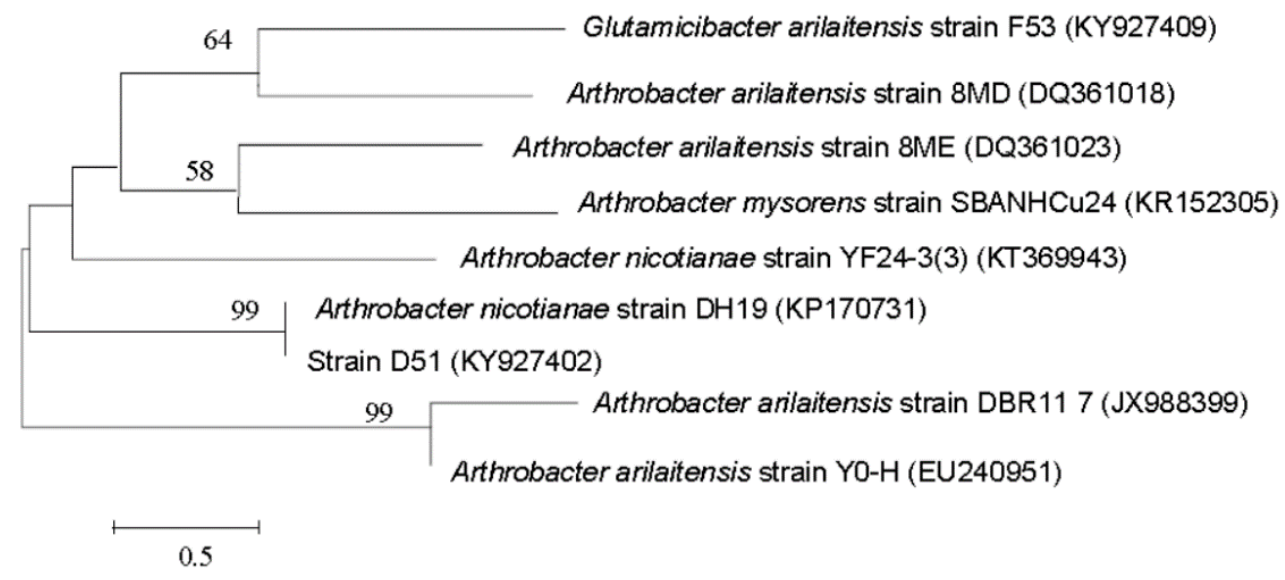

Figure 2. Neighbor-joining phylogenetic tree of Arthrobacter nicotianae D51 and closely related strains. GenBank accession numbers for the16S rRNA sequences used in the tree reconstruction are given in parentheses.

\subsection{Ammonium Removal Performance of Strain D51 with Different Dosages of Added $\mathrm{Cu}^{2+}$}

To verify the heterotrophic nitrification by $A$. nicotianae D51, cells were cultivated using ammonium as the sole nitrogen source (Figure 3). The results demonstrated that strain D51 was able to remove ammonia nitrogen. Significant differences in the ammonium removal percentage and cell growth were observed among $\mathrm{Cu}^{2+}$ concentrations of $0-0.5 \mathrm{mg} \cdot \mathrm{L}^{-1}(P<0.05)$. The highest removal efficiencies of ammonium nitrogen and $\mathrm{TN}$ were $98.70 \%$ and $79.90 \%$ in the control treatment (without copper ions addition), respectively. The ammonia nitrogen decreased from 53.17 to $0.69 \mathrm{mg} \cdot \mathrm{L}^{-1}$ in response to $48 \mathrm{~h}$ of incubation with an ammonia nitrogen removal ratio of $1.09 \mathrm{mg} \cdot(\mathrm{L} \cdot \mathrm{h})^{-1}$. The growth rate and ammonia nitrogen removal efficiency of this strain would be inhibited by the addition of $\mathrm{Cu}^{2+}$. Additionally, the inhibitory effect became progressively stronger with increasing $\mathrm{Cu}^{2+}$ concentrations. Strain D51 grew slowly but could not conduct biological nitrogen removal efficiently when the concentrations of $\mathrm{Cu}^{2+}$ exceeded $0.25 \mathrm{mg} \cdot \mathrm{L}^{-1} \cdot \mathrm{Cu}^{2+}$ greatly inhibited ammonia nitrogen removal of strain D51 at $0.5 \mathrm{mg} \cdot \mathrm{L}^{-1}$. 


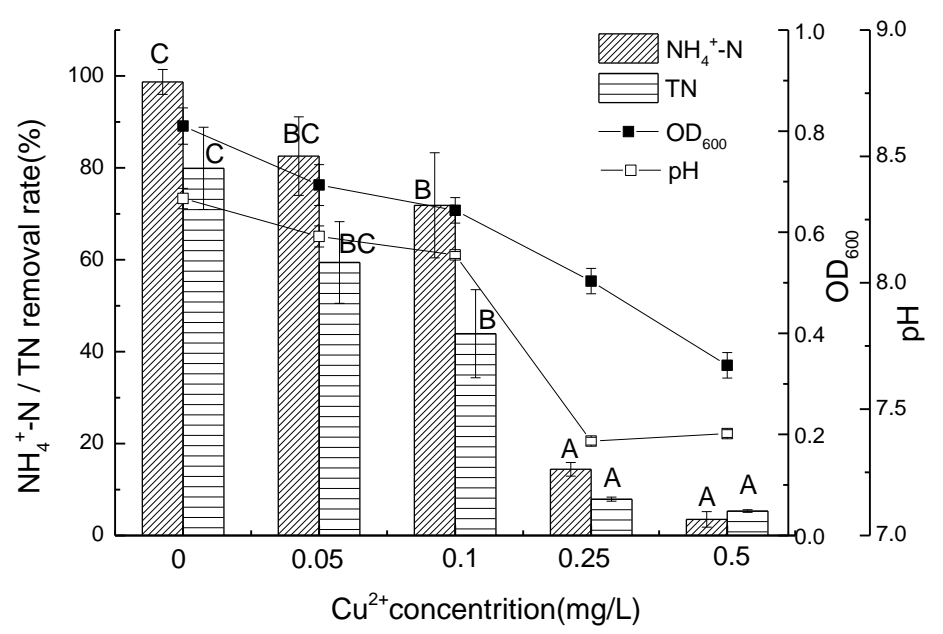

Figure 3. Effects of $\mathrm{Cu}^{2+}$ on ammonium nitrogen removal performance of strain D51.

\subsection{Nitrate Nitrogen Removal Performance of Strain D51 with Different Dosages of Added Cu ${ }^{2+}$}

Various concentrations of $\mathrm{Cu}^{2+}$ were prepared to confirm the short-term response of the denitrifying activity to $\mathrm{Cu}^{2+}$ dosage. Figure 4 shows the changes of nitrogenous compounds, cell growth, and $\mathrm{pH}$ for A. nicotianae D51 in culture medium containing nitrate as the sole nitrogen source in the presence of $\mathrm{Cu}^{2+}$. The results showed that different concentrations of $\mathrm{Cu}^{2+}$ had great effects on nitrate nitrogen reduction and bacterial growth. The nitrate nitrogen decreased from 58.73 to $12.73 \mathrm{mg} \cdot \mathrm{L}^{-1}$, corresponding to an optimum removal efficiency of $78.32 \%$, while the average nitrate removal rate by strain D51 in the presence of $0.05 \mathrm{mg} \mathrm{Cu}^{2+} \cdot \mathrm{L}^{-1}$ was $0.96 \mathrm{mg} \cdot(\mathrm{L} \mathrm{h})^{-1}$ within $48 \mathrm{~h}$ $(\mathrm{P}<0.05)$. The maximum $\mathrm{TN}$ removal percentage was $65.08 \%$ under the condition of $0.05 \mathrm{mg} \cdot \mathrm{L}^{-1} \mathrm{Cu}^{2+}$ with an initial nitrate nitrogen concentration of about $50 \mathrm{mg} \cdot \mathrm{L}^{-1}$ after $48 \mathrm{~h}$ of cultivation. These results illustrated that $0.05 \mathrm{mg} \mathrm{Cu}{ }^{2+} \cdot \mathrm{L}^{-1}$ enhanced the efficiency of denitrification, resulting in an increase of $12 \%$ compared with the control treatment. Throughout the denitrification process, low concentrations $\left(<0.05 \mathrm{mg} \cdot \mathrm{L}^{-1}\right)$ of $\mathrm{Cu}^{2+}$ could reduce the nitrite nitrogen accumulation. The aforementioned results showed that A. nicotianae D51 exhibited intense denitrification capacity when nitrate was used as the sole nitrogen source in the presence of low concentrations of $\mathrm{Cu}^{2+}\left(<0.05 \mathrm{mg} \cdot \mathrm{L}^{-1}\right)$. However, strain D51 was extremely sensitive to $\mathrm{Cu}^{2+}$ inhibition. The nitrate and TN removal efficiencies only reached $21.75 \%$ and $18.59 \%$, respectively, when the $\mathrm{Cu}^{2+}$ concentration reached $0.25 \mathrm{mg} \cdot \mathrm{L}^{-1}$. The cell growth and nitrogen removal nearly stopped when the $\mathrm{Cu}^{2+}$ concentration was $>0.5 \mathrm{mg} \cdot \mathrm{L}^{-1}$.

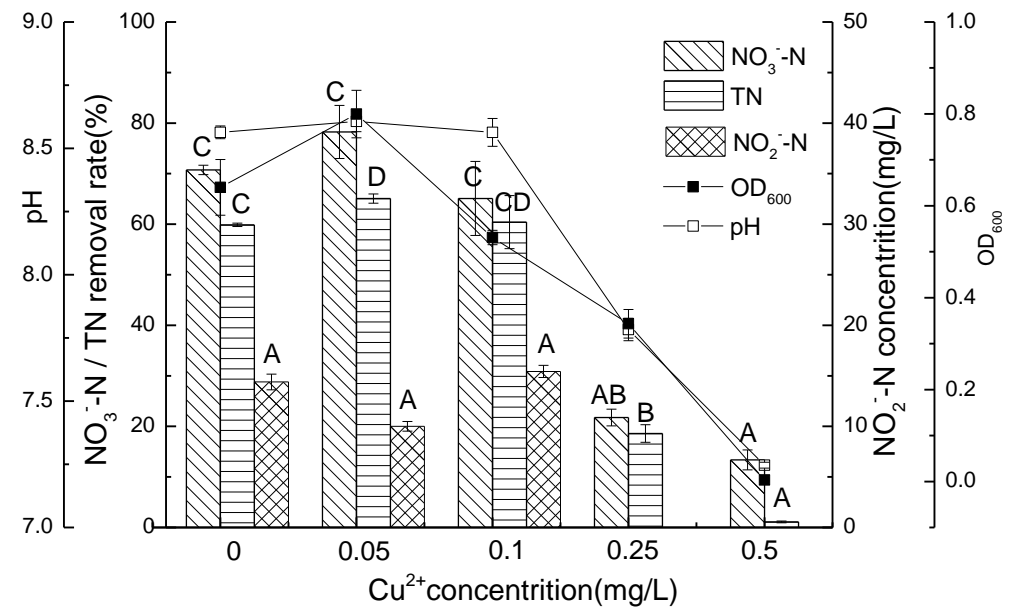

Figure 4. Effects of $\mathrm{Cu}^{2+}$ on nitrate nitrogen removal performance of strain D51. 


\subsection{Nitrite Nitrogen Removal Performance of Strain D51 with Different Dosages of Added $\mathrm{Cu}^{2+}$}

Nitrite was further used as the sole nitrogen source to assess the possibility of aerobic denitrification by $A$. nicotianae D51 in the presence of $\mathrm{Cu}^{2+}$. Figure 5 illustrates the nitrite and TN degradation capabilities of strain D51 in DM-2 under aerobic conditions. The results revealed that different concentrations of $\mathrm{Cu}^{2+}$ had markedly different effects on nitrite nitrogen reduction efficiencies $(P<0.05)$. The nitrite and TN removal efficiencies increased to $68.97 \%$ and $61.68 \%$ when the $\mathrm{Cu}^{2+}$ was increased to $0.05 \mathrm{mg} \cdot \mathrm{L}^{-1}$. The removal of nitrite nitrogen increased by $8 \%$ when compared to the control treatment $\left(0 \mathrm{mg} \mathrm{Cu}^{2+} \mathrm{L}^{-1}\right)$. The optimum growth rate and denitrification capacity of strain D51 occurred in the presence of $0.05 \mathrm{mg} \cdot \mathrm{L}^{-1}$ of $\mathrm{Cu}^{2+}$. As the concentrations of $\mathrm{Cu}^{2+}$ increased from 0.1 to $0.5 \mathrm{mg} \cdot \mathrm{L}^{-1}$, the removal rate of nitrite nitrogen gradually decreased from $48.38 \%$ to $20.51 \%$. These results demonstrated that the nitrite nitrogen removal ability of strain D51 could be promoted by low concentrations of $\mathrm{Cu}^{2+}$ (less than $0.05 \mathrm{mg} \cdot \mathrm{L}^{-1}$ ).

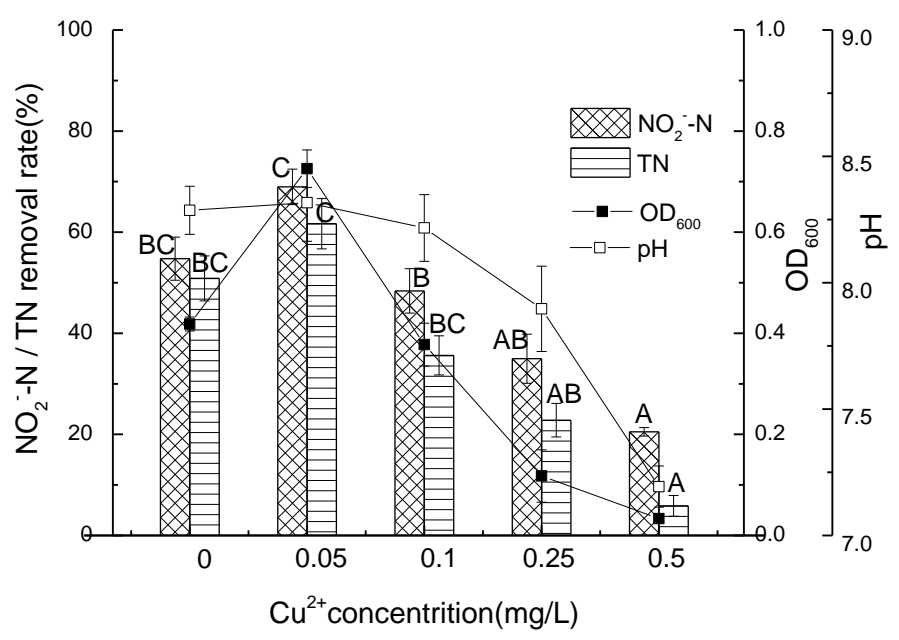

Figure 5. Effects of $\mathrm{Cu}^{2+}$ on nitrite nitrogen removal performance of strain D51.

\subsection{Assessment for Gas Detection}

$\mathrm{N}_{2} \mathrm{O}$ in the headspace was monitored by GC when the ammonium, nitrate, and nitrite were separately used as the sole nitrogen sources. As shown in Table 2, the net production was 0.0271, 0.0144 , and $0.2163 \mathrm{mg} \cdot \mathrm{L}^{-1}$ when ammonium, nitrate, and nitrite were used as the sole nitrogen source, respectively. These findings demonstrated that the amount of $\mathrm{N}_{2} \mathrm{O}$ was very low. Moreover, the amount of $\mathrm{N}_{2} \mathrm{O}$ production from nitrite was higher than that from nitrate and ammonium. The nitrogen removal performances of ammonium, nitrate, and nitrite by strain D51 and the production of nitrogen gases implied that heterotrophic nitrification and aerobic denitrification were conducted by this strain.

Table 2. The concentration of $\mathrm{N}_{2} \mathrm{O}$ produced during nitrogen removal process.

\begin{tabular}{|c|c|c|c|}
\hline Nitrogen Resource & $\begin{array}{l}\text { Control Groups } \\
\left(\mathrm{mg} \cdot \mathrm{L}^{-1}\right)\end{array}$ & $\begin{array}{l}\text { Experimental Groups } \\
\left(\mathrm{mg} \cdot \mathrm{L}^{-1}\right)\end{array}$ & $\begin{array}{l}\text { Net Production } \\
\left(\mathrm{mg} \cdot \mathrm{L}^{-1}\right)\end{array}$ \\
\hline $\mathrm{NH}_{4}^{+}-\mathrm{N}$ & 0.0009 & 0.0280 & 0.0271 \\
\hline $\mathrm{NO}_{3}{ }^{-}-\mathrm{N}$ & 0.0140 & 0.0284 & 0.0144 \\
\hline $\mathrm{NO}_{2}{ }^{-}-\mathrm{N}$ & 0.0160 & 0.2323 & 0.2163 \\
\hline
\end{tabular}

\section{Discussion}

To date, Arthrobacter nicotianae has been recovered from soil and vegetation. Several studies have been reported that $A$. nicotianae was highly capable of absorbing heavy metals, such as cadmium and chromium (III), from aqueous solutions [23,24]. Wang et al. [25] isolated A. nicotianae DH19 from ginseng rhizosphere soil, which could efficiently degrade pentachloronitrobenzene 
(PCNB), hexachlorocyclohexane, and cyhalothrin. In addition, previous studies demonstrated that various enzymes were produced by $A$. nicotianae, including choline oxidase and creatine amidinohydrolase [26,27]. However, to the best of our knowledge, this is the first study to report the heterotrophic aerobic nitrification-denitrification capacity of $A$. nicotianae.

The experimental results obtained using ammonium as the sole nitrogen source showed that A. nicotianae D51 had the capability to remove ammonium in the presence of $\mathrm{Cu}^{2+}$. The ammonia nitrogen removal rate of strain D51 was $1.09 \mathrm{mg} \cdot(\mathrm{L} \cdot \mathrm{h})^{-1}$, which was similar to that of Pseudomonas alcaligenes AS-1 (1.15 mg. $\left.(\mathrm{L} \cdot \mathrm{h})^{-1}\right)$ [28] and Pseudomonas sp. (1.38 $\left.\mathrm{mg} \cdot(\mathrm{L} \cdot \mathrm{h})^{-1}\right)$ [29], but higher than that of Bacillus sp. LY $\left(0.43 \mathrm{mg} \cdot(\mathrm{L} \cdot \mathrm{h})^{-1}\right)$ [30]. The ammonium removal capacity of strain D51 was intensely inhibited by $\geq 0.5 \mathrm{mg} \mathrm{Cu}^{2+} \cdot \mathrm{L}^{-1}$, which was similar to the results reported for Aeromonas sp. HN-02 and Pseudomonas stutzeri PCN-1 [31,32]. However, high concentrations of $\mathrm{Cu}^{2+}$ do not inhibit the growth rate and heterotrophic nitrification of some microorganisms. For instance, Kim et al. [1] reported that $31.77 \mathrm{mg} \cdot \mathrm{L}^{-1}$ of $\mathrm{Cu}^{2+}$ did not hinder the growth rate and ammonium removal rate of Bacillus sp. PK15. Qiao et al. [33] reported that $63.55 \mathrm{mg} \mathrm{Cu}^{2+} \cdot \mathrm{L}^{-1}$ promoted the activity of key enzymes of heterotrophic nitrification. Overall, these studies indicated that the effects of $\mathrm{Cu}^{2+}$ on different bacteria were different when ammonium was used as the sole nitrogen source.

It is worth noting that neither nitrate nor nitrite nitrogen were detected during ammonium nitrogen conversion by $A$. nicotianae D51, which was consistent with the results observed for Pseudomonas tolaasii Y-11 [19], but opposite to the finding that nitrite accumulation is inevitable when ammonium is used as the nitrogen source for Alcaligenes sp. S84S3, Chryseobacterium sp. R31, and Acinetobacter junii YB. [34-36]. This phenomenon might be because the production of nitrate and nitrite were reduced rapidly by nitrate reductase and nitrite reductase [37]. However, strain D51 has been shown to effectively remove ammonium from nitrification medium. The TN decreased and the maximum removal efficiency was up to $79.90 \%$, while $\mathrm{N}_{2} \mathrm{O}$ production was detected when ammonium was used as the sole nitrogen source. These results confirmed that strain D51 could conduct heterotrophic nitrification although no nitrate and/or nitrite accumulation occurred under aerobic conditions. In this study, the intermediate products were detected when nitrate was used as the sole nitrogen source (Figure 4), indicating that strain D51 conducts aerobic denitrification. The $\mathrm{N}_{2} \mathrm{O}$ levels in the headspace when nitrate and nitrite were used as the sole nitrogen sources under aerobic conditions were monitored by GC, and the results indicated that strain D51 conducts aerobic denitrification. The $\mathrm{N}_{2} \mathrm{O}$ production during nitrate nitrogen conversion by strain D51 occurred via nitrite as an intermediate, which further indicated that strain D51 can conduct aerobic denitrification. We speculated that $\mathrm{N}_{2} \mathrm{O}$ could be further converted to $\mathrm{N}_{2}$ because the amount of $\mathrm{N}_{2} \mathrm{O}$ was very low when nitrite, nitrate, and ammonium were used as the sole nitrogen sources, respectively.

It is well known that nitrification is a process of acid production, but the $\mathrm{pH}$ was always alkaline in this study. This may indicate that strain D51 conducted nitrification first, followed by denitrification, and that the acidic chemicals produced during nitrification were neutralized by alkaline chemicals generated via denitrification under aerobic conditions, which has also been reported by He et al. [38].

Previous studies have reported that copper easily interacts with radicals, which makes copper very toxic [39]. For example, copper has the potential to disrupt the biological activities of many key enzymes, probably via its ability to chelate sulfhydryl groups [40]. In addition, heavy metals can be stimulatory, inhibitory, or even toxic to microbial metabolism depending on their concentrations [13]. Copper is an essential microelement for microbial growth; however, it can inhibit metabolism of the cells in excess. In this study, copper could promote the nitrate and nitrite nitrogen removal efficiency of strain D51 and reduce accumulation of intermediate products when the copper ion concentration was $0.05 \mathrm{mg} \cdot \mathrm{L}^{-1}$. This was probably because copper ions could stimulate metabolism and promote the synthesis of enzymes utilized for microbial growth under low concentrations [41]. Overall, the results indicated that trace levels of copper had significant effects on strain D51, but that the addition of copper in excess inhibited the growth and denitrification ability of strain D51. 
In this study, the ammonium removal efficiency was inhibited as long as $\mathrm{Cu}^{2+}$ was added, but the nitrate and nitrite nitrogen removal ability were promoted by $0.05 \mathrm{mg} \cdot \mathrm{L}^{-1} \mathrm{Cu}^{2+}$ relative to the control. This may have occurred because the effects on the enzymes that catalyzed each step in the nitrification and denitrification process differed [32]. These findings may also indicate that $\mathrm{Cu}^{2+}$ affected the activities of the denitrifying enzymes [42]. In addition, the accumulation of nitrite nitrogen was lower than that in the control treatment in the presence of $0.05 \mathrm{mg} \mathrm{Cu}^{2+} \mathrm{L}^{-1}$. A Cu-containing nitrite reductase encoded by the nirK gene has been confirmed to be the key enzyme in the denitrification pathway, and the addition of $\mathrm{Cu}^{2+}$ could increase the nitrite reductase (NiR) activity, which would result in less nitrite accumulation and improved denitrification efficiency $[43,44]$.

The above results show that strain D51 could perform heterotrophic nitrification and aerobic denitrification at $15{ }^{\circ} \mathrm{C}$ in simulated wastewater containing copper ions, and neither nitrate nor nitrite nitrogen were detected during ammonium nitrogen conversion by strain D51. Therefore, A. nicotianae D51 has potential application for the treatment of nitrogenous wastewater containing $\mathrm{Cu}^{2+}$ at low temperatures, especially ammonium wastewater containing low concentrations of $\mathrm{Cu}^{2+}$.

\section{Conclusion}

Strain D51 was newly isolated from soil and identified as Arthrobacter nicotianae by morphological, phospholipid fatty acids (PLFAs), and 16S rRNA gene sequence analyses. A. nicotianae D51 had the capability to conduct heterotrophic nitrification-aerobic denitrification because of its ability to transform nitrite, nitrate, or ammonium nitrogen into $\mathrm{N}_{2} \mathrm{O}$ under aerobic conditions. The growth and nitrification capacity of strain D51 would always be inhibited when $\mathrm{Cu}^{2+}$ was added to the medium. Moreover, the growth and denitrification efficiency of strain D51 could be promoted by low concentrations of $\mathrm{Cu}^{2+}\left(\leq 0.05 \mathrm{mg} \cdot \mathrm{L}^{-1}\right)$, but excess $\mathrm{Cu}^{2+}\left(\geq 0.1 \mathrm{mg} \cdot \mathrm{L}^{-1}\right)$ would be harmful to the growth and nitrogen removal efficiency of this strain. Taken together, these results illustrated that strain D51 could be used in the treatment of industrial wastewater containing copper ions.

Author Contributions: X.C. and T.H. conceived and designed the experiments; X.C., K.L., T.H., Y.W., X.Z., E.X. and N.D. carried out the experiments; X.C. and K.L. analyzed the data; X.C. and Z.L. wrote the main manuscript text and all authors reviewed the manuscript.

Funding: This work was supported by the National Key Research and Developmental Program of China (2017YFC0404705) and the Scientific Research Innovation Project of Chongqing, China (No. CYB17063).

Conflicts of Interest: The authors declare no conflict of interest.

\section{References}

1. Kim, J.K.; Park, K.J.; Cho, K.S.; Nam, S.W.; Park, T.J.; Bajpai, R. Aerobic nitrification-denitrification by heterotrophic Bacillus strains. Bioresour. Technol. 2005, 96, 1897-1906. [CrossRef] [PubMed]

2. Peng, Y.Z.; Zhu, G.B. Biological nitrogen removal with nitrification and denitrification via nitrite pathway. Appl. Microbiol. Biotechnol. 2006, 73, 15-26. [CrossRef] [PubMed]

3. Robertson, L.A.; Kuenen, J.G. Combined heterotrophic nitrification and aerobic denitrification in Thiosphaera pantotropha and other bacteria. Antonie. Van. Leeuwenhoek. 1990, 57, 139-152. [CrossRef] [PubMed]

4. Zhang, Q.L.; Liu, Y.; Ai, G.M.; Miao, L.L.; Zheng, H.Y.; Liu, Z.P. The characteristics of a novel heterotrophic nitrification aerobic denitrification bacterium, Bacillus methylotrophicus strain L7. Bioresour. Technol. 2012, 108, 35-44. [CrossRef] [PubMed]

5. Duan, J.M.; Fang, H.D.; Su, B.; Chen, J.F.; Lin, J.M. Characterization of a halophilic heterotrophic nitrification-aerobic denitrification bacterium and its application on treatment of saline wastewater. Bioresour. Technol. 2015, 179, 421-428. [CrossRef] [PubMed]

6. Yang, X.P.; Wang, S.M.; Zhang, D.W.; Zhou, L.X. Isolation and nitrogen removal characteristics of an aerobic heterotrophic nitrifying-denitrifying bacterium, Bacillus subtilis A1. Bioresour. Technol. 2011, 102, 854-862. [CrossRef] [PubMed] 
7. Ji, B.; Wang, H.Y.; Yang, K. Tolerance of an aerobic denitrifier (Pseudomonas stutzeri) to high $\mathrm{O}_{2}$ concentrations. Biotechnol. Lett. 2014, 36, 719-722. [CrossRef] [PubMed]

8. Khardenavis, A.A.; Kapley, A.; Purohit, H.J. Simultaneous nitrification and denitrification by diverse Diaphorobacter sp. Appl. Microbiol. Biotechnol. 2007, 77, 403-409. [CrossRef] [PubMed]

9. O'Loughlin, E.J.; Sims, G.K.; Traina, S.J. Biodegradation of 2-methyl, 2-ethyl, and 2-hydroxypyridine by an arthrobacter sp. isolated from subsurface sediment. Biodegradation 1999, 10, 93-104. [CrossRef] [PubMed]

10. Verstraete, W.; Alexander, M. Heterotrophic nitrification by Arthrobacter sp. J. Bacteriol. 1972, 110, $955-961$. [PubMed]

11. Fu, F.L.; Wang, Q. Removal of heavy metal ions from wastewaters: A review. J. Environ. Manag. 2011, 92, 407-418. [CrossRef] [PubMed]

12. Chen, H.; Yu, J.J.; Jia, X.Y.; Jin, R.C. Enhancement of anammox performance by Cu (II), Ni (II) and Fe (III) supplementation. Chemosphere 2014, 117, 610-616. [CrossRef] [PubMed]

13. Altas, L. Inhibitory effect of heavy metals on methane-producing anaerobic granular sludge. J. Hazard. Mater. 2009, 162, 1551-1556. [CrossRef] [PubMed]

14. Zhang, Q.Q.; Zhang, Z.Z.; Guo, Q.; Chen, Q.Q.; Jin, R.C.; Jia, X.Y. Variation in the performance and sludge characteristics of anaerobic ammonium oxidation inhibited by copper. Sep. Purif. Technol. 2015, 142, 108-115. [CrossRef]

15. Feng, B.; Fang, Z.; Hou, J.C.; Ma, X.; Huang, Y.L.; Huang, L.Q. Effects of heavy metal wastewater on the anoxic/aerobic-membrane bioreactor bioprocess and membrane fouling. Bioresour. Technol. 2013, 142, 32-38. [CrossRef] [PubMed]

16. Kimura, Y.Y.; Kazuichi, I. Evaluation of inhibitory effects of heavy metals on anaerobic ammonium oxidation (anammox) by continuous feeding tests. Appl. Microbiol. Biotechnol. 2014, 98, 6965-6972. [CrossRef] [PubMed]

17. Felgate, H.; Giannopoulos, G.; Sullivan, M.J.; Gates, A.J.; Clarke, T.A.; Baggs, E.; Rowley, G.; Richardson, D.J. The impact of copper, nitrate and carbon status on the emission of nitrous oxide by two species of bacteria with biochemically distinct denitrification pathways. Environ. Microbiol. 2012, 14, 1788-1800. [CrossRef] [PubMed]

18. Ochoa-Herrera, V.; León, G.; Banihani, Q.; Jim, A.; Reyes Sierra-Alvarez, F. Toxicity of copper (II) ions to microorganisms in biological wastewater treatment systems. Sci. Total Environ. 2011, 412, 380-385. [CrossRef] [PubMed]

19. He, T.X.; Li, Z.L.; Sun, Q.; Xu, Y.; Ye, Q. Heterotrophic nitrification and aerobic denitrification by Pseudomonas tolaasii Y-11 without nitrite accumulation during nitrogen conversion. Bioresour. Technol. 2016, 200, 493-499. [CrossRef] [PubMed]

20. He, T.X.; Ye, Q.; Sun, Q.; Cai, X.; Ni, J.P.; Li, Z.L.; Xie, D.T. Removal of nitrate in simulated water at low temperature by a novel psychrotrophic and aerobic bacterium, Pseudomonas taiwanensis Strain J. Biomed. Res. Int. 2018. [CrossRef] [PubMed]

21. Song, Y.; Deng, S.P.; Acosta-Martínez, V.; Katsaliro, E. Characterization of redox-related soil microbial communities along a river floodplain continuum by fatty acid methyl ester (FAME) and 16S rRNA genes. Appl. Soil Ecol. 2008, 40, 499-509. [CrossRef]

22. Pratt, B.; Riesen, R.; Johnston, C.G. PLFA analyses of microbial communities associated with PAH-contaminated riverbank sediment. Microb. Ecol. 2012, 64, 680-691. [CrossRef] [PubMed]

23. Tsuruta, T.; Umenai, D.; Hatano, T.; Hirajima, T.; Sasaki, K. Screening micro-organisms for cadmium absorption from aqueous solution and cadmium absorption properties of Arthrobacter nicotianae. Biosci. Biotechnol. Biochem. 2014, 78, 1791-1796. [CrossRef] [PubMed]

24. Hatano, T.; Tsuruta, T. Removal and recovery of chromium (III) from aqueous chromium (III) using Arthrobacter nicotianae cells. Adv. Microbiol. 2017, 7, 487-497. [CrossRef]

25. Wang, Y.; Wang, C.; Li, A.; Gao, J. Biodegradation of pentachloronitrobenzene by Arthrobacter nicotianae DH19. Lett. Appl. Microbiol. 2015, 61, 403-410. [CrossRef] [PubMed]

26. Ribitsch, D.; Winkler, S.; Gruber, K.; Karl, W.; Wehrschütz-Sigl, E.; Eiteljörg, I.; Schratl, P.; Remler, P.; Stehr, R.; Bessler, C.; et al. Engineering of choline oxidase from Arthrobacter nicotianae for potential use as biological bleach in detergents. Appl. Microbiol. Biotechnol. 2010, 87, 1743-1752. [CrossRef] [PubMed] 
27. Dai, J.; Zhang, L.P.; Kang, Z.; Chen, J.; Du, J.C. High-level production of creatine amidinohydrolase from Arthrobacter nicotianae 23710 in escherichia coli. Appl. Biochem. Biotechnol. 2015, 175, 2564-2573. [CrossRef] [PubMed]

28. Su, J.J.; Yeh, K.S.; Tseng, P.W. A Strain of Pseudomonas sp. isolated from piggery wastewater treatment systems with heterotrophic nitrification capability in Taiwan. Curr. Microbiol. 2006, 53, 77-81. [CrossRef] [PubMed]

29. Jin, R.; Liu, T.; Liu, G.; Zhou, J.; Huang, J.; Wang, A. Simultaneous heterotrophic nitrification and aerobic denitrification by the marine origin bacterium Pseudomonas sp. ADN-42. Appl. Biochem. Biotechnol. 2015, 175, 2000-2011. [CrossRef] [PubMed]

30. Zhao, B.; He, Y.L.; Zhang, X.F. Nitrogen removal capability through simultaneous heterotrophic nitrification and aerobic denitrification by Bacillus sp. LY. Environ. Technol. 2010, 31, 409-416. [CrossRef] [PubMed]

31. Chen, M.; Wang, W.C.; Feng, Y.; Zhu, X.H.; Zhou, H.Z.; Tan, Z.L.; Li, X.D. Impact resistance of different factors on ammonia removal by heterotrophic nitrification-aerobic denitrification bacterium Aeromonas sp. HN-02. Bioresour. Technol. 2014, 167, 456-461. [CrossRef] [PubMed]

32. Gui, M.Y.; Chen, Q.; Ma, T.; Zheng, M.S.; Ni, J.R. Effects of heavy metals on aerobic denitrification by strain Pseudomonas stutzeri PCN-1. Appl. Microbiol. Biotechnol. 2017, 101, 1717-1727. [CrossRef] [PubMed]

33. Qiao, N.; Gao, B.; Zhang, L.Y.; Chen, R.J. Factors affecting the denitrification property of heterotrophic nitrification-aerobic denitrifier. Fresenius. Environ. Bull. 2012, 21, 3773-3778.

34. Kundu, P.; Pramanik, A.; Dasgupta, A.; Mukherjee, S.; Mukherjee, J. Simultaneous heterotrophic nitrification and aerobic denitrification by chryseobacterium sp. R31 isolated from a battoir wastewater. Biomed. Res. Int. 2014. [CrossRef] [PubMed]

35. Ren, Y.X.; Yang, L.; Liang, X. The characteristics of a novel heterotrophic nitrifying and aerobic denitrifying bacterium, Acinetobacter junii YB. Bioresour. Technol. 2014, 171, 1-9. [CrossRef] [PubMed]

36. Angar, Y.; Kebbouche-Gana, S.; Djelali, N.E.; Khemili-Talbi, S. Novel approach for the ammonium removal by simultaneous heterotrophic nitrification and denitrification using a novel bacterial species co-culture. World J. Microbiol. Biotechnol. 2016, 32, 1-14. [CrossRef] [PubMed]

37. Zhao, B.; Yi, L.H.; Hughes, J.; Xiao, F.Z. Heterotrophic nitrogen removal by a newly isolated Acinetobacter calcoaceticus HNR. Bioresour. Technol. 2010, 101, 5194-5200. [CrossRef] [PubMed]

38. He, T.X.; Li, Z.L.; Xie, D.T.; Sun, Q.; Xu, Y.; Ye, Q.; Ni, J.P. Simultaneous nitrification and denitrification with different mixed nitrogen loads by a hypothermia aerobic bacterium. Biodegradation 2018, 29, 159-170. [CrossRef] [PubMed]

39. Nies, D.H. Microbial heavy-metal resistance. Appl. Microbiol. Biotechnol. 1999, 51, 730-750. [CrossRef] [PubMed]

40. Epstein, E. Health issues related to beneficial use of biosolids. Proc. Water Environ. Fed. 2001, $79-87$. [CrossRef]

41. Chen, H.; Chen, Q.Q.; Jiang, X.Y.; Hu, H.Y.; Shi, M.L.; Jin, R.C. Insight into the short- and long-term effects of $\mathrm{Cu}$ (II) on denitrifying biogranules. J. Hazard. Mater. 2016, 304, 448-456. [CrossRef] [PubMed]

42. Black, A.; Hsu, P.C.L.; Hamonts, K.E.; Clough, T.J.; Condon, L.M. Influence of copper on expression of nirS, norB and nosZ and the transcription and activity of NIR, NOR and $\mathrm{N}_{2} \mathrm{OR}$ in the denitrifying soil bacteria Pseudomonas stutzer. Microb. Biotechnol. 2016, 9, 381-388. [CrossRef] [PubMed]

43. Zhu, X.Y.; Chen, Y.G.; Chen, H.; Li, X.; Peng, Y.Z.; Wang, S.Y. Minimizing nitrous oxide in biological nutrient removal from municipal wastewater by controlling copper ion concentrations. Appl. Microbiol. Biotechnol. 2013, 97, 1325-1334. [CrossRef] [PubMed]

44. Gao, H.F.; Li, C.Q.; Ramesh, B.; Hu, N. Cloning, purifcation and characterization of novel Cu-containing nitrite reductase from the Bacillus frmus GY-49. World J. Microbiol. Biotechnol. 2018, 34, 1-10. [CrossRef] [PubMed]

(C) 2019 by the authors. Licensee MDPI, Basel, Switzerland. This article is an open access article distributed under the terms and conditions of the Creative Commons Attribution (CC BY) license (http:/ / creativecommons.org/licenses/by/4.0/). 